\title{
The Effect of Germicides on the Longevity of Cut Flowers
}

\author{
Rodney B. Jones ${ }^{1}$ and Megan Hill \\ Institute of Plant Sciences, Knoxfield, Victorian Department of Food and Agriculture, PO Box 174, \\ Ferntree Gully, Vic. 3156, Australia \\ Additional index words. Alstroemeria, Dendranthema, Dianthus, Freesia, Iris, Gerbera, Gypsophila, Lilium, Narcissus, Rosa, \\ Scilla, Tulipa, chlorine, bromine, microbial contamination, '8-hydroxyquinoline citrate
}

\begin{abstract}
The effect of DICA (50 mg-liter $\left.{ }^{-1}\right)$ BCDMH (12 mg available chlorine/liter), and HQC (250 mg-liter]) on the longevity of 14 popular cut flower species was assessed. Longevity was significantly extended in: Rosa hybrida L. 'Gabrielle' and Scilla campanulata L. Squill. by all germicides; Lilium parkmannii L. 'Nepal', Gerbera jamesonii L. 'Mercy', and Narcissus tazetta L. 'Fortune' by DICA and BCDMH; Gypsophila paniculata L. 'R22' by DICA and HQC; and Freesia hybrida Eckl. ex Klatt 'White Bergunden' by BCDMH. No effect on longevity was found in Dendranthema grandiflora (Ramat) Kitamura. 'Horim', Dianthus caryophyllus L. 'Medea', Dianthus barbatus L., Iris hollandica L. 'Pearl', and Gerbera jamesonii L. 'Double Delight'. Longevity was significantly reduced by DICA in Alstroemeria aurantiaca $\mathbf{L}$. 'Mona Lisa' and Tulipa hybrida L. 'Apeldoorn'. Analysis of microbial concentrations showed that proliferation was effectively controlled by DICA and BCDMH, but not by HQC. Levels of up to $10^{6} \mathrm{cfu} \cdot \mathrm{ml}^{-1}$ were detected in water, indicating that species not affected by germicides can tolerate these microbial quantities. Fresh weight and solution uptake data indicated that germicides acted primarily by improving solution uptake. Longevity was significantly reduced in $R$. hybrida 'Gabrielle' and D. caryophyllus 'Medea' flowers placed in solutions containing high counts of microorganisms $\left(>10^{8} \mathrm{cfu} \cdot \mathrm{ml}^{-1}\right)$ isolated from D. caryophyllus or $R$. hybrida. Chemical names used: 1-bromo-3-chloro-5,5-dimethylhydantoin (BCDMH); sodium dichloroisocyanuric acid (DICA); 8-hydroxyquinoline citrate (HQC).
\end{abstract}

The most common cause of the termination of vase life in cut flowers is water stress (Halevy, 1976). The rapid proliferation of microorganisms in vase water is thought to result in xylem blockage, water stress, and a subsequent reduction in cut flower longevity (van Doom and Perik, 1990); a variety of germicides have been suggested to prevent this problem (Aarts, 1957; Larsen and Cromarty, 1966; Larsen and Cromarty, 1967; Larsen and Frolich, 1969; Marousky, 1968, 1969, 1971; Kofranek et al., 1974; Halevy and Mayak, 1981). Many studies have correlated an increase in bacterial counts in the vase water with decreased longevity (Larsen and Frolich, 1969; Clerkx et al., 1989; vanDoom and Perik, 1990). While Zagory and Reid (1986) isolated three microorganisms from the holding solutions of cut carnation flowers that specifically reduced longevity of cut carnations, roses, and chrysanthemums, it has not been shown conclusively how the presence of microorganisms adversely affects longevity. It has been suggested, however, that the presence of micoorganisms in vase water can: 1) cause physical plugging of the cut stem (Burdett, 1970; Lineburger and Steponkus, 1976; van Doom and Perik, 1990), 2) release toxic metabolites and/or enzymes (Mayak and Accati, 1979; Accati et al., 1980; Put and Rambouts, 1989), or 3) evolve damaging levels of ethylene (Fujino et al., 1983).

Despite these results, the response of many cut flowers to germicides is highly variable among species and variety. Longevity was consistently improved in cut roses, for example, with the addition of germicides (Marousky, 1969; Clerkx et al., 1989; van Doom and Perik, 1990). Vase life in cut carnations, however, has

Received for publication 29 Jan. 1992. Accepted for publication 21 Sept. 1992. We wish to thank Janyce Truett for her skilled technical assistance and Dolph de Boer, Martin Mebalds, and Kaija Jordan for their help with microbial counts. We also wish to thank the following for supplying the flowers used in this study: The Tesselaar Group, van Wyk and Son Flower Supply, Australian Roses, Maxiflora, Nick and Elaine Walley, and Ch. Webb \& Co. The cost of publishing this paper was defrayed in part by the payment of page charges. Under postal regulations, this paper therefore must be hereby marked advertisement solely to indicate this fact. ${ }^{1}$ To whom all correspondence should be addressed. been improved with germicides in some studies (Aarts, 1957; Larsen and Frolich, 1969; Mayak et al., 1977), while in others there was no effect (Marousky, 1976; vanDoorn et al., 1991). In fact, van Doorn et al. (1991) found that vase life of cut carnation flowers was unaffected when high levels of bacteria $\left(10^{8} \mathrm{cfu} \cdot \mathrm{ml}^{-1}\right)$ or 250 mg.liter ${ }^{-1}$ DICA were added to vase water. Similar conflicting results were found with HQC on Freesia (Woodson, 1987; AccatiGaribaldi and Deambrogio, 1990). Further, many studies tested the effect of commercial preservatives where it is difficult to determine whether any beneficial effect on the flowers resulted from the sugar, the germicide, or some other compound contained in the formulation (Staby et al., 1978; Healy and Lang, 1989; Dan and Griffith, 1990).

Results from most studies are, therefore, variable and difficult to compare due to a lack of consistency in establishing criteria for termination of vase life and in experimental conditions. This study attempts to clarify the effect of DICA, BCDMH, and HQC on the vase life and microbial counts found in the vase water of 14 popular species of cut flower. Additionally, assessment of the impact of microbes on flower longevity was made. Little information is available on the efficacy of BCDMH, which is being used in increasing amounts by flower growers and wholesalers as it has the advantages of being more effective than chlorine in lower concentrations and maintains efficacy over a longer period (H. Tayama, personal communication).

\section{Materials and Methods}

Effect of germicide solutions. Plowers were collected from commercial flower growers and transported to the laboratory in water within $4 \mathrm{~h}$ of harvest. Stems of each species were trimmed to a uniform length and placed in test tubes containing the following treatments: 1) tapwater (control), 2) $50 \mathrm{mg}$ (a.i.) sodium dichloroisocyanurate/liter (DICA) 60\% a.i. Bioguard pool sanitiser,

Abbreviations: cfu, colony-forming units; FW, fresh weight. 
Table 1. Criteria used for determining end of vase life.

\begin{tabular}{ll}
\hline \hline Genus & Termination of vase life \\
\hline Alstroemeria & First sign of leaf yellowing \\
Dendranthema & First sign of petal wilting or drop, leaf yellowing \\
Dianthus & First sign of petal inrolling/wilting \\
Freesia & Half the open flowers wilted \\
Iris & First sign of petal wilting \\
Gerbera & More than one-third of the petals brown/wilted \\
Gypsophila & 50\% florets wilted \\
Lilium & First sign of petal browning or drop \\
Narcissus & First sign of petal wilting \\
Rosa & More than one-third petals wilted or bent neck \\
Scilla & First sign of petal wilting \\
Tulipa & First sign of petal wilting or drop \\
\hline
\end{tabular}

Biolab, Melbourne, Australia), 3) BCDMH $12 \mathrm{mg}$ available chlorine/liter (Nylate, Wobelea Pty, Melbourne); and 4) $250 \mathrm{mg}$ HQC (Ajax Chemicals Pty, Melbourne). The $\mathrm{pH}$ of each solution was determined as: distilled water, 6.9; DICA, 5.9; BCDMH, 6.5; HQC, 3.6.

Test tubes and solutions, with and without the flower, were weighed daily to determine fresh weight $(\mathrm{FW})$ and solution uptake. Solutions were replaced every 3 days to ensure germicides remained active. Ten replications of each treatment were arranged in a randomized-block design, and each trial was conducted twice. Plowers were placed at $20 \mathrm{C} \pm 1 \mathrm{C}, 65 \% \pm 3 \%$ relative humidity (RH), under $24 \mathrm{~h}$ light of $10 \mu \mathrm{mol} \cdot \mathrm{m}^{-2} \cdot \mathrm{s}^{-1}$. Vase life was assessed daily and was considered terminated according to the criteria listed in Table 1.

Microbial suspensions. Samples of vase water were taken from $R$. hybrida 'Gabrielle' and D. caryophyllus 'Medea' at the start of the experiment ( 0 days), and 2, 6, and 9 days after placement in 50 $\mathrm{mg} \cdot$ liter $^{-1}$ DICA, BCDMH (12 $\mathrm{mg} \cdot$ liter $^{-1}$ available chlorine), and $250 \mathrm{mg} \cdot$ liter $^{-1} \mathrm{HQC}$. After decimal dilutions, samples were plated out on Kings B media, incubated at 20C for 5 days, and counted.
Concentrated microbial suspensions were made by placing 10 stems each of $R$. hybrida 'Gabrielle' and D. caryophyllus 'Medea' in tapwater at 20C for 10 days. Samples of the suspensions were plated on Kings B medium to determine counts. Freshly cut stems of $R$. hybrida 'Gabrielle' and D. caryophyllus 'Medea' were placed in the vase water containing $\approx 10^{8} \mathrm{cfu} \cdot \mathrm{m}^{-1}$; control stems were placed in distilled water. Vase life was assessed at 20C.

\section{Results and Discussion}

Effect of germicide solutions. The most effective germicides were DICA and BCDMH; both improved longevity in six species, but DICA had no effect on six other species, and BCDMH had no effect on eight others (Table 2). HQC increased vase life in three species and had no significant effect on 11 species. Vase life was significantly increasedin $R$. hybrida 'Gabrielle' and $S$. campanulata by DICA, BCDMH, and HQC; L. parkmannii 'Nepal', G. jamesonii 'Mercy' and G. paniculata by DICA and BCDMH; N. tazetta 'Fortune' by DICA and HQC; and F. hybrida 'White Bergunden' by BCDMH (Table 2). The $\mathrm{pH}$ of the germicide solutions did not appear to affect FW (Fig. 1) or vase life (Table 2) in species treated with HQC solutions ( $\mathrm{pH}$ 3.6) compared with DICA and BCDMH (pH 5.9 and 6.5, respectively).

Previous studies have shown that the longevity of roses, gerberas, and Gypsophila has been consistently improved with germicide solutions. Longevity of cut 'Sonia', 'Ilona', 'Polka', and 'Frisco' roses, for example, was increased with HQC and DICA in similar concentrations to those used in this study (Marousky, 1969; van Doorn, 1988; van Doorn and Perik, 1990). Alternatively, increasing the number of microorganisms in the vase water resulted in poor vase life in cut 'Sonia' roses and 'Fleur' gerberas (Clerkx et al., 1989). Longevity has been improved in G. jamesonii 'Wageningen Rood' with sodium hypochlorite (van Meeteren, 1978 ) and in $G$. paniculata with quaternary ammonium compounds (Tandler et al., 1986).

Longevity was unaffected by any germicide in several species, namely D. grandiflora 'Horim', D. caryophyllus 'Medea', D.

Table 2. Effect of DICA, BCDMH, and HQC on vase life (days) of selected cut flower species. Flowers were placed in DICA ( $\left.50 \mathrm{mg} \cdot 1 \mathrm{iter}^{-1}\right), \mathrm{BCDMH}\left(12 \mathrm{mg} \cdot \mathrm{liter}^{-1}\right.$ available chlorine), or HQC $\left(250 \mathrm{mg} \cdot \mathrm{liter}^{-1}\right)$, with tap water as a control, and vase life was assessed under the criteria in Table 1. Each species was tested twice, and values are the means of both trials. Data was subjected to ANOVA using the Genstat 5 package. LSD was determined at $P=0.05$.

\begin{tabular}{lrrrrr}
\hline \hline & \multicolumn{5}{c}{ Vase life (days) } \\
\cline { 2 - 5 } Species & Control & DICA & BCDMH & 8HQC & LSD \\
\hline A. aurantica & 10.4 & 9.4 & 10.2 & 10.7 & 0.8 \\
D. grandiflora & 13.9 & 16.4 & 13.6 & 13.4 & 3.2 \\
D. caryophyllus & 6.0 & 6.3 & 6.6 & 6.6 & 0.7 \\
D. barbatus & 11.3 & 11.8 & 11.6 & 11.5 & 2.0 \\
F. hybrida & 6.5 & 6.5 & 7.3 & 7.0 & 0.8 \\
I. hollandica & 5.0 & 5.3 & 5.4 & 5.7 & 1.7 \\
Gerbera jamesonii & & & & & \\
\multicolumn{1}{c}{ 'Double Delight' } & 10.6 & 11.9 & 13.1 & 12.2 & 3.1 \\
'Mercy' & 12.1 & 15.8 & 14.8 & 11.6 & 1.9 \\
Gypsophila & & & & & \\
$\quad$ paniculata & 9.4 & 10.7 & 10.2 & 10.9 & 1.0 \\
L. parkmannii & 6.5 & 8.1 & 8.0 & 7.6 & 1.4 \\
N. tazetta & 3.2 & 4.0 & 3.7 & 3.9 & 0.7 \\
R. hybrida & 10.8 & 14.5 & 15.3 & 12.8 & 1.6 \\
S. campanulata & 11.7 & 16.6 & 13.6 & 13.7 & 1.7 \\
T. hybrida & 5.7 & 5.2 & 5.5 & 5.3 & 0.5 \\
\hline
\end{tabular}




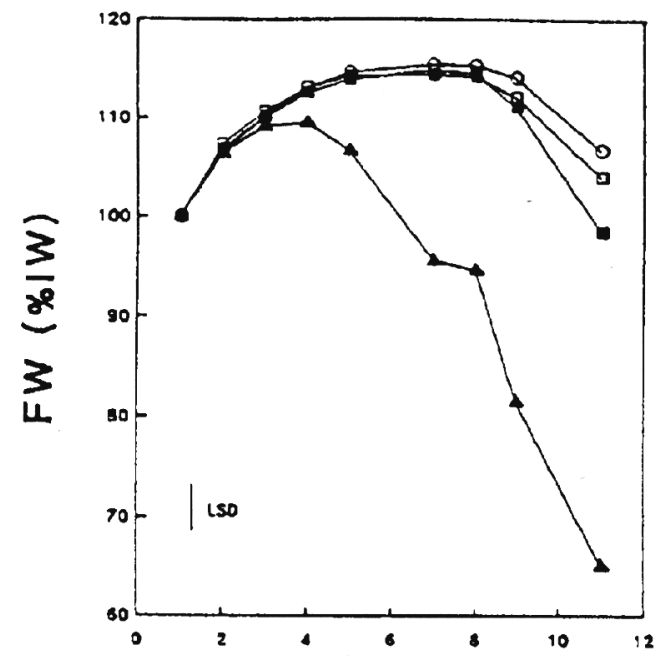

A

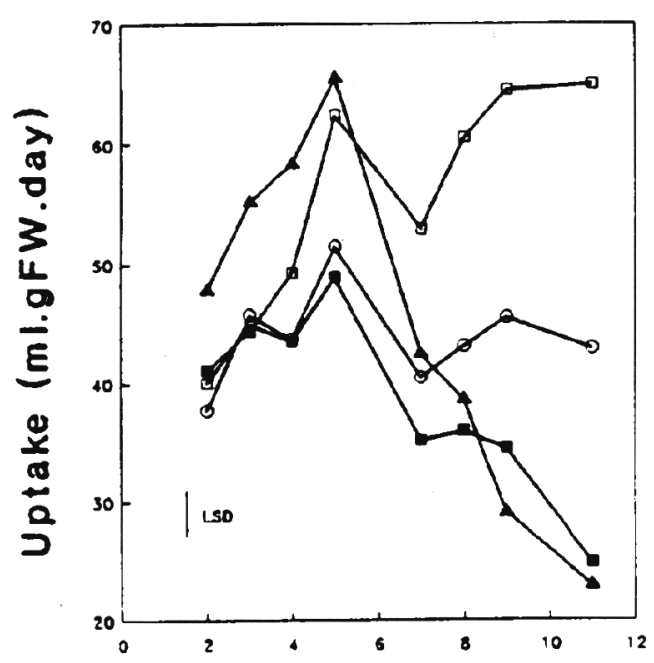

A
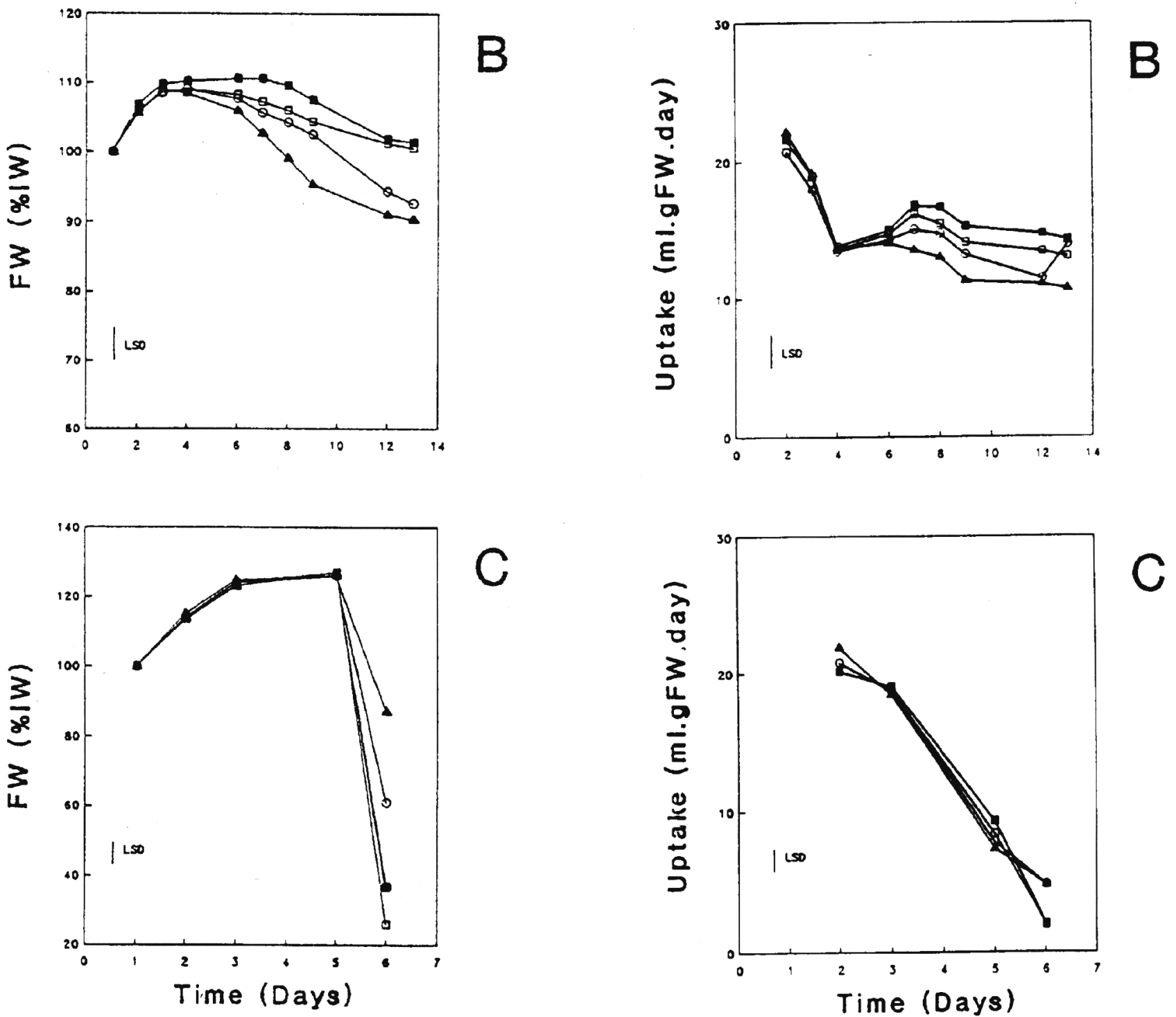

Fig. 1. Effect of tapwater (A), $50 \mathrm{mg}$ DICA/liter ( $\square$ ), BCDMH (12 mg available chlorine/liter) (更), and $250 \mathrm{mg} \mathrm{HQC/liter} \mathrm{(O)} \mathrm{on} \mathrm{FW} \mathrm{of} \mathrm{cut} R$. hybrida 'Gabrielle' (A), D. caryophyllus 'Medea' (B), and T. hybrida 'Apeldoorn' (C) flowers. FW is expressed as percentage of initial fresh weight (IW). LSD was calculated at $P=$ 0.05 .

Fig. 2. Effect of tapwater (A), $50 \mathrm{mg}$ DICA/liter ( $\square$ ), BCDMH (12 mg available chlorine/liter) ( $\mathbf{\square}$ ), and $250 \mathrm{mg} \mathrm{HQC/liter} \mathrm{(O)} \mathrm{on} \mathrm{solution} \mathrm{uptake} \mathrm{of} \mathrm{cut} R$. hybrida 'Gabrielle' (A), D. caryophyllus 'Medea' (B), and T. hybrida 'Apeldoorn' (C) flowers. Uptake is expressed as milliliters/gram FW per day. LSD was calculated at $P=0.05$. 
Table 3. Microbial counts in vase water solutions containing individual stems of $R$. hybrida 'Gabrielle' and D. caryophyllus 'Medea'. Solutions consisted of: tapwater, DICA (50 $\left.\mathrm{mg} \cdot \mathrm{liter}^{-1}\right)$, BCDMH (12 mg.liter ${ }^{-1}$ available chlorine), or HQC (250 mg.liter $\left.{ }^{-1}\right)$, and were sampled $0,2,6$, and 9 days after harvest. Values are the mean of six samples each from a tube containing an individual stem.

\begin{tabular}{lcccc}
\hline \hline & \multicolumn{4}{c}{ Microbial counts $\left(\mathrm{cfu} \cdot \mathrm{ml}^{-1}\right)$} \\
\cline { 2 - 5 } Species and & \multicolumn{4}{c}{ Days } \\
\cline { 2 - 5 } compound & 0 & 2 & 6 & 9 \\
\hline & & R. hybrida & \\
Water & $2 \times 10^{4}$ & $10^{6}$ & $10^{5}$ & $4 \times 10^{5}$ \\
DICA & 0 & 0 & 0 & 0 \\
BCMH & 0 & 0 & 0 & 0 \\
HQC & 0 & $10^{2}$ & $2 \times 10^{5}$ & $10^{6}$ \\
& & D. caryophyllus & & $10^{6}$ \\
Water & $5 \times 10^{4}$ & $10^{6}$ & $4 \times 10^{6}$ & 0 \\
DICA & 0 & 0 & 0 & $3 \times 10^{6}$ \\
BCDMH & 0 & $10^{6}$ & $6 \times 10^{5}$ & $10^{7}$ \\
HQC & 0 & $7 \times 10^{3}$ & $10^{6}$ & \\
\hline
\end{tabular}

barbatus, I. hollandica 'Pearl', and G. jamesonii 'Double Delight' (Table 2). Responses to germicides can, therefore, vary widely among species, as well as between cultivars of the same species as longevity was improved by DICA and BCDMH in G. jamesonii 'Mercy', but not in 'Double Delight'. Similarly, HQC improved longevity in F. hybrida 'Aurora' (Woodson, 1987), but had no effect on F. hybrida 'Royal Crown' (Accati-Garibaldi and Deambrogio, 1990).

Other studies have also found a variable effect of germicides on carnation and chrysanthemum longevity. The application of DICA or silver nitrate had no effect on longevity in D. caryophyllus (van Doorn et al., 1991), and HQC did not affect longevity in $D$. caryophyllus 'Red Sim' (Marousky, 1976). Mayak et al. (1977), however, found that silver nitate improved longevity in 'White Sim' carnations. In contrast to our results, longevity in D. grandiflora improved when quaternary ammonium compounds were used as germicides (D'hont and van der Sprong, 1989).

Longevity was significantly reduced in A. aurantiaca 'Mona Lisa' and T. hybrida 'Appeldoorn' by $50 \mathrm{mg}$ DICA/liter. Vase life has been extended in T. hybrida and A. aurantiaca by commercial preservatives (Staby, 1978; Healy and Lang, 1989), but it is not known whether this resulted from the germicide contained in the formulation. Certain cut flower species are known to be sensitive to specific germicides. Vase life of 'Sonia' roses, for example, declined with the application of DICA at $50 \mathrm{mg} \cdot \operatorname{liter}^{-1}$ (D. Joyce, personal communication), while the Australian native flowers Thryptomene calycina (Lindl.) Stapf and Telopea speciosissima R.Br. are both sensitive to Physan $\left(200 \mathrm{mg} \cdot \mathrm{g}^{-1}\right)$ and benzalkonium chloride at $50 \mathrm{mg} \cdot \mathrm{g}^{-1}$ (J. Faragher, unpublished data).

Rosa hybrida 'Gabrielle', D. caryophyllus 'Medea', and $T$. hybrida 'Apeldoorn' were chosen as examples of flowers where longevity was improved, unchanged, or decreased, respectively, by the application of germicides (Table 2). Fresh weight was maintained at a significantly higher level in stems treated with DICA, BCDMH, or HQC in R. hybrida 'Gabrielle' (Fig. 1A) than in stems treated with water. Fresh weight of stems treated with DICA, BCDMH, and HQC continued to increase up to 8 days after harvest, then declined (Fig. 1A). Solution uptake improved with all treatments for 5 days (Fig. 2A), then declined rapidly in roses kept in water. Uptake continued to improve with DICA and remained relatively constant with HQC, while uptake in BCDMH declined, but at a lower rate than in water.
There was no significant difference in FW and solution uptake between $D$. caryophyllus stems treated with germicides or water (Figs. 1B and 2B). Although FW was maintained in stems treated with HQC for 7 days, this had no significant effect on vase life (Table 2). Possibly, vase life was at least partially determined by ethylene production by the flowers, as the carnations were not treated with silver thiosulphate after harvest.

Fresh weight of tulips (Fig. 1C) was similar for flowers placed in water or germicides for 5 days after harvest, but was significantly lower in stems treated with DICA after 6 days (Fig 1C). Solution uptake was not affected by germicide solutions for the life of the cut tulips (Fig. 2C), indicating that the detrimental effect of DICA was not due to a decrease in solution uptake and FW, but possible tissue toxicity.

Microbial suspensions. DICA and BCDMH effectively controlled microbial growth during the vase life of $R$. hybrida 'Gabrielle' (Table 3), but up to $10^{6} \mathrm{cfu} \cdot \mathrm{ml}^{-1}$ were consistently detected in water and in solutions containing HQC. Microbial growth in solutions containing cut 'Medea' carnations was controlled by DICA only, as up to $10^{6} \mathrm{cfu} \cdot \mathrm{ml}^{-1}$ were recorded in tapwater, $\mathrm{BCDMH}$, and HQC solutions after 9 days (Table 3). The uniform appearance of bacterial colonies on plates inoculated with $\mathrm{BCDMH}$ solutions indicated that one microbial strain may have been resistant.

The addition of two mixed microbial populations grown from $D$. caryophyllus 'Medea' and $R$. hybrida 'Gabrielle' flower solutions at the higher concentration of $10^{8} \mathrm{cfu} \cdot \mathrm{ml}^{-1}$ significantly reduced vase life in 'Gabrielle' roses and 'Medea' carnations

Table 4. Vase life of individual stems of $R$. hybrida 'Gabrielle' and $D$. caryophyllus 'Medea' placed in: sterilized water, or with mixed microbial populations (adjusted to $10^{8} \mathrm{cfu} \cdot \mathrm{ml}^{-1}$ ) grown in vase water containing 10 stems each of $R$. hybrida 'Gabrielle' or $D$. caryophyllus 'Medea'. LSD was determined at $P=0.05$

\begin{tabular}{lcc}
\hline \hline & \multicolumn{2}{c}{ Vase life (days) } \\
\cline { 2 - 3 } $\begin{array}{l}\text { Source of } \\
\text { microbes }\end{array}$ & $\begin{array}{l}\text { R. hybrida } \\
\text { 'Gabrielle' }\end{array}$ & $\begin{array}{c}\text { D. caryophyllus } \\
\text { 'Medea' }\end{array}$ \\
\hline Water (none) & 11.5 & 11.0 \\
$R$. hybrida & 5.6 & 5.5 \\
$D$. caryophyllus & 1.5 & 6.7 \\
LSD & 1.8 & 1.8 \\
\hline
\end{tabular}


(Table 4). Microbes grown from D. caryophyllus 'Medea' were particularly deleterious to 'Gabrielle' roses (Table 4), indicating the possibility that microbial populations from carnation flowers are more toxic to other cut flower species. Other soluble or suspended materials not measured in these trials may have been responsible for the observed decline in longevity. Preliminary trials indicated that a mixed microbial population $\left(10^{8} \mathrm{cfu} \cdot \mathrm{ml}^{-1}\right)$ isolated from $D$. caryophyllus was significantly more toxic to 'Gabrielle' roses than microbes isolated from several other flower species, including Protea neriifolia and T. hybrida. Similarly, Zagory and Reid (1986) found that longevity in 'Cara Mia' roses was significantly reduced by pure strains of Pseudomonas and yeast isolated from carnation flowers.

Van Doorn et al. (1991) reported that a mixed microbial population $\left(10^{7} \mathrm{cfu} \cdot \mathrm{ml}^{-1}\right)$ had no effect on the vase life of $D$. caryophyllus 'Scania' and 'White Sim', but higher levels $\left(>10^{8} \mathrm{cfu} \cdot \mathrm{ml}^{-1}\right)$ significantly reduced vase life (van Doorn et al., 1992). Our results support these data as microbial levels of $10^{6} \mathrm{cfu} \cdot \mathrm{ml}^{-1}$ (Table 3) did not affect longevity in D. caryophyllus 'Medea', whereas longevity was significantly reduced by $10^{8} \mathrm{cfu} \cdot \mathrm{ml}^{-1}$ (Table 4$)$.

Apparently, sensitive species, exemplified by roses in this study, are adversely affected by relatively low microbial levels $\left(<10^{6} \mathrm{cfu} \cdot \mathrm{ml}^{-1}\right)$ and benefit from the application of germicides (Table 2). Microbial concentrations of $10^{6} \mathrm{cfu} \cdot \mathrm{ml}^{-1}$ were routinely recorded in the untreated tapwater 3 days after flower stems were added (Table 3). Based on our results (Table 2), lilies, gerberas, gypsophila, daffodils, freesia, and bluebell may behave in a similar manner. However, carnations appeared to be tolerant of microbial counts up to $\approx 10^{7} \mathrm{cfu} \cdot \mathrm{ml}^{-1}$. Other species that may be included in this class are Dendranthema (chrysanthemums), iris, alstromeria, and tulip, i.e., those species unaffected by germicides (Table 2). Higher microbial levels $\left(>10^{8} \mathrm{cfu} \cdot \mathrm{ml}^{-1}\right)$, however, may lead to accelerated wilting (Table 4). Microbial concentrations of this magnitude can occur under commercial conditions, as counts as high as $10^{8} \mathrm{cfu} \cdot \mathrm{ml}^{-1}$ have been recorded in vase water in a survey of European and American florists and supermarkets (W.G. van Doorn, 1992, personal communication).

In tolerant species, such as D. caryophyllus, placed in water with microbial counts $<10^{8} \mathrm{cfu} \cdot \mathrm{ml}^{-1}$, bacterial blockage of xylem vessels may not be the primary cause of wilting (Table 2). Probably, cut flower senescence is controlled by a combination of factors, some physical, such as xylem vessel blockage caused by bacteria or air embolism, and others genetically determined, such as a loss of membrane integrity (Woodson, 1991). When water uptake is not hindered by physical xylem blockage, genetically determined factors may result in the decline in the ability of flowers to take up water and retain water in cells resulting in wilting.

\section{Literature Cited}

Aarts, J.F.T. 1957. Ove de houdbaarheid van snijbloemen. Mededelingen van de landbouwhogeschool te Wageningen/Nederland 57: 1-62.

Accati-Garibaldi, E. and F. Deambrogio. 1990. Postharvest physiology of Freesia refracta hybrida. Proc. XXIII Int. Hort. Conf.: 3392 (Abstract) Accati, E., S. Mayak, and I. Gentile-Abbatista. 1980. The role of bacterial metabolite(s) in affecting water uptake by carnation flowers. Acta Hort. 113:137-142.

Burdett, A.N. 1970. The cause of bent neck in cut roses. J. Amer. Soc. Hort. Sci. 95:427-431.

Clerkx, A.C.M., A. Boekestein, and H.M.C. Put. 1988. Scanning electron microscopy of the stem of cut flowers of Rosa cv. Sonia and Gerbera $c v$. Fleur. Acta Hort. 261:97-106.
Dan, A.J. and L.P. Griffith. 1990. Effects of commercial floral preservatives on four types of cut flowers. Proc. Fla. State Hort. Soc. 103:214217.

D'hont, K. and J. van der Sprong. 1988. Postharvest treatment of chrysanthemum. Acta Hort. 261:305-308.

Fujino, D.W., MS. Reid, and G.E. Vandermolen. 1983. Identification of vascular blockages of cut maidenhair (Adiantum raddianum) fronds. Scientia Hort. 21:381-388.

Halevy, A.H. 1976. Treatments to improve water balance of cut flowers. Acta Hort. 64:223-226.

Halevy, A.H. and S. Mayak. 1981. Senescence and postharvest physiology of cut flowers-Part 2. Hort. Rev. 3:59-143.

Healy, W. and D. Lang. 1989. Postharvest handling of Alstoemeria. HortScience 24:641-643.

Kofranek, A.M., H.C. Kohl, and J. Kubota. 1974. A slow-release chlorine compound as a vase water additive. Florist Rev. 154(4000):21,63-65.

Larsen, F.E. and R.W. Cromarty. 1966. Effect of N-dimethylamino succinamic acid (Alar) on micro-organism growth in relation to cut flower senescence. Proc. Amer. Soc. Hort. Sci. 89:723-726.

Larsen, F.E. and R.W. Cromarty. 1967. Micro-organism inhibition by 8hydroxyquinoline citrate as related to cut flower senescence. Proc. Amer. Soc. Hort. Sci. 90:546-549.

Larsen, F.E. and M. Frolich. 1969. The influence of 8-hydroxyquinoline citrate, $\mathrm{N}$-dimethylamino succinamic acid, and sucrose on respiration and water flow in 'Red Sim' cut carnations in relation to flower senescence. J. Amer. Soc. Hort. Sci. 94:289-292.

Lineberger, R.D. and P. Steponkus. 1976. Identification of vascular occlusions in cut roses. J. Amer. Soc. Hort. Sci. 101:246-250.

Marousky, F.J. 1968. Physiological role of 8-hydroxyquinoline citrate and sucrose in extending vase life and improving quality of cut gladiolus. Proc. Fla. State Hort. Soc. 81:409-414.

Marousky, F.J. 1969. Vascular blockage, water absorption, stomatal opening, and respiration of cut 'Better Times' roses treated with 8hydroxyquinoline citrate and sucrose. J. Amer. Soc. Hort. Sci. 94:223226.

Marousky, F.J. 1971. Inhibition of vascular blockage and increased moisture retention in cut roses induced by $\mathrm{pH}$, 8-hydroxyquinoline citrate and sucrose. J. Amer. Soc. Hort. Sci. 96:38-41.

Mayak, S., E. Accati-Garibaldi, and A.M. Kofranek. 1977. Carnation flower longevity: Microbial populations as related to silver nitrate stem impregnation. J. Amer. Soc. Hort. Sci. 102:637-639.

Put, H.C.M. and F.M. Rambouts. 1989. The influence of purified microbial pectic enzymes on the xylem amatomy, water uptake and vase life of Rosa cultivar 'Sonia'. Scienta Hort. 38:147-160.

Staby, G.L., T.D. Erwin, and A.A. De Hertogh. 1978. Cut flower life of tulips as influenced by preservative and water quality. Flor. Rev. 162(4200):22-23.

Tandler, J., Y. Mor, H. Spiegelstein, and S. Mayak. 1986. Chemical treatments to improve the quality of cut Gypsophila flowers. Acta Hort. 181443449 .

vanDoorn, W.G. 1988. Role of physiological processes, microorganisms, and air embolism in vascular blockage of cut rose flowers. Acta Hort. 261:27-34.

van Doorn, W.G. and R.R. Perik. 1990. Hydroxyquinoline citrate and low $\mathrm{pH}$ prevent vascular blockage in stems of cut rose flowers by reducing the number of bacteria. J. Amer. Soc. Hort. Sci. 115:979-981.

van Doom, W.G., D. Zagory, Y. de Witte, and H. Harkema. 1991. Effects of vase-water bacteria on the senescence of cut carnation flowers. Postharvest Biology and Technology 1:161-168.

van Meeteren, U. 1978. Water relations and keeping-quality of cut Gerbera flowers. 1. The cause of stem break. Scientia Hort. 8:65-74.

Woodson, W.R. 1987. Postharvest handling of bud-cut Freesia flowers. HortScience 22:456-458.

Woodson, W.R. 1991. Biotechnology of floricultural crops. HortScience 26:1029-1033.

Zagory, D. and M.S. Reid. 1986. Role of vase solution microorganisms in the life of cut flowers. J. Amer. Soc. Hort. Sci. 111: 154-158. 